\title{
A REVIEW ON PERFORMANCE CHARACTERISTICS OF HEAT EXCHANGER WITH CORRUGATED TYPE TUBE AND NANO FLUIDS
}

\author{
B. Senthil Kumar ${ }^{\# 1}$, R.Gokulprasath ${ }^{\# 2}$, N.Jenu Rooban ${ }^{\# 3}$ and R.Kavin Krishna ${ }^{\# 4}$ \\ \#1 Associate Professor, Sri Ramakrishna Engineering College, \\ \#2, \#3, \#4 Sri Ramakrishna Engineering College,
}

\section{ABSTRACT}

Heat transfer enhancement techniques are widely used in the applications of air conditioning, refrigeration, Power stations, Radiators and chemical reactors. Therefore several techniques have been used to enhance the heat transfer rate in order to increase the efficiency of the heat exchanger. One of the main tools used in heat exchanger to create turbulence flow with the help of corrugated tubes. The current paper investigates about the different arrangements of corrugated tubes used in tube heat exchangers in the recent years are studied at the turbulence zone and also the overall enhancement ratio.

KEYWORDS :Heat transfer, Corrugated tube, Nano fluids, Nusselt number, Friction Factor,

Reynolds number.

\section{Corresponding author: B. Senthilkumar}

\section{INTRODUCTION}

In thermal engineering systems heat exchangers plays a major role to transfer heat from solid body to fluid or between fluids. The applications such as chemical processing industries, thermal power plants, radiators, air conditioning systems, etc... are widely depends upon the heat exchangers to have a better efficiency. Traditional heat exchanger coolants have poor properties of heat transfer coefficient and also low thermal conductivity. This heat transfer mainly depends upon the (1).the types of tube used (2).the types of fluid used (3).the material of tube used. In another words, the thermal conductivity is also depends upon the turbulence level of the flowing fluid so that corrugated tubes can be used to increase the turbulence level of the flowing fluid as a result in increase in convective heat transfer coefficient. Polymer based corrugated heat exchanger over metallic based corrugated tube heat exchanger can be used to enhance the property of anticorrosion and life. And also polymers are good insulators and has more chemical resistance and more durable. The major disadvantage is low thermal conductivity of 0.3 to $0.5 \mathrm{~W} / \mathrm{mk}$ while the other materials stainless steel has $16 \mathrm{~W} / \mathrm{mk}$ and aluminium has $205 \mathrm{~W} / \mathrm{mk}$ [1]. By adding carbon nanotubes (CNT), and reducing the wall thickness we can increase the thermal conductivity. Some researches have reported that addition of CNT increases the thermal conductivity upto 14-53 W/mk [2]. Usage of Nano fluids as coolant fluid can also increases the convective heat transfer coefficient.

\section{CORRUGATED TUBES}

Among the turbulent flow devices, the corrugated tubes are the best one to create turbulent flow because of their geometrical arrangements. It has its wide applications in heat regenerators. To study the characteristics of corrugated tubes, the following parameters are should be known, 
- Reynolds number $(\mathrm{Re})$

- Corrugation angle $(\Theta)$

- Corrugation height $(\mathrm{H})$

- $\quad$ Pitch (P)

Corrugated tubes are widely used to transfer heat at a faster rate by turbulent flow, which makes the fluid mixing. The flow creates a turbulence by mixing all the stream flow lines which leads to heat convection and more tangential velocity near at the tube walls. The higher Reynolds number is created to produce more turbulent flow. The corrugation height effect also increases the heat transfer by heat conduction. The materials used for Corrugated tubes are

- Mild steel

- Aluminium[3]

- Stainless steel

- Copper

This includes the implementation in double pipe heat exchangers with counter flow applications. This paper investigates, In double pipe heat exchangers the inner pipe be as corrugated tube or outer pipe as corrugated tube or both the pipes are corrugated tubes. The thickness of the pipe may varies from $0.1 \mathrm{~mm}$ to $10 \mathrm{~mm}$. The required corrugated geometry can be achieved by special machines.

\subsection{THE HEAT TRANSFER ENHANCEMENT}

Heat transfer enhancing is the important techniques to increase the effectiveness of the heat exchanger. The following methods can be used to enhance the heat transfer,

- Use of secondary heat surface area.

- Promoting boundary layer seperation

- Introducing secondary flows (swirl flow)

- Increasing the turbulence level of the fluid

- Promoting counter flow in heat exchangers

- Increasing the effective length of heat exchangers

- Optimizing the friction factor[4]

- More pressure drop causes high heat transfer rate.

- Using nano fluids as working fluid[5]

\section{NANO FLUIDS}

Nano fluids are the one which contains nano particles, which are in the size of a nanometer. It was first discovered by Sir Stephan Choi in 1995. The nano particles are mixed or colloided in a base fluid to obtain the nano fluid. The common base fluids used are water, ethylene glycol and oil. These nano fluids have various engineering applications such as coolant in automobiles, fuel cells, pharmaceutical process, heat exchanger, domestic refrigerator, grinding machine.

In the recent years, many researches have been done on nano fluids in the domain of heat exchanger. They use the nano fluids as a fluid to make the heat transfer process quicker. The nano fluids exhibit excellent thermal conductivity and good convective heat transfer coefficient compared with the base fluid and so they replace the conventional base fluids. The heat transfer is increased by increasing the concentration of the nano particles in the base fluid. The common used nano fluids are $\mathrm{Al}_{2} \mathrm{O}_{3}, \mathrm{CuO}, \mathrm{Fe}_{3} \mathrm{O}_{4}, \mathrm{Fe}_{2} \mathrm{O}_{3}, \mathrm{SiO}_{2}, \mathrm{TiO}_{2}, \mathrm{Ag}, \mathrm{Cu}, \mathrm{ZnO}, \mathrm{SiC}$, nano-diamond, graphite, and carbon nano tubes. 


\subsection{PREPARATION OF NANO FLUID}

Preparing of Nano-fluids is the most important part in analysis of heat transfer setup. Nanofluids is prepared by any of these two ways,

(i) one step method

two step method.

There are two techniques to prepare Nano fluids (two steps and single step[6]). Those techniques have been implemented by using different types of physical(PVD) and chemical(CVD) methods to ensure that the mixture remains in stability. The two steps of method have been conducted by synthesizing Nano powders, and then dispersed to liquid.

In single step method, the nanoparticles are prepared and suspended to the basefluids [7]. Modern nanofabrication technologies give great opportunities to produce materials at nanometre scale (nanoparticles). Generally, nanoparticles are available in the powderform with higher thermal conductivities than conventional fluids. Nanoparticles materials usually used in the preparation of Nano fluidsare made of metals, oxides or carbides Das et al. [8]. Nano fluids are prepared by dispersing nanoparticles with average sizes less than $100 \mathrm{~nm}$ in base fluids such as water, ethylene glycol or oil. Nano fluidsmust be stable suspensions with no particles agglomeration and no chemical reaction.Nano fluids can be prepared by using two-step or single-step method Wang and Mujumdar[9]. In two-step method, nanoparticles (nanopowder) are produced then nanoparticles are dispersed in the basefluids using ultrasonic equipment Wang and Mujumdar [10]. The limitations of this technique are the clustering and sedimentations of nanoparticles in a base fluid. The single-step method combines the fabrication of nanoparticles and the preparation of nanofluids into onestep. A direct evaporation single-step method is one of the common techniques. In this technique, the nanofluid is prepared by condensing nanoparticles vapourin a low-vapour-pressure-base fluids Eastman et al. [11]. The advantages of single-step method are to minimize the agglomeration of nanoparticles and prevent oxidation of nanoparticles. However, two-step method is preferred due to its low cost, therefore, it is appropriate for large-scale Nano fluids production. The two-step method is used to prepare Nano fluids in most of previous experimental studies. Nano fluids are prepared by suspended $\mathrm{TiO} 2$ nanoparticles in water by using ultrasonically equipment based on the two-step method by a number of investigators [12-16].

\section{LITERATURE REVIEW}

Table 1: Experimental analysis of heat exchanger with corrugated tubes comparing to plain tubes

\begin{tabular}{|c|c|c|c|c|c|}
\hline $\begin{array}{c}\text { AUTHOR } \\
\& \\
\text { CORRUGATED } \\
\text { TYPE }\end{array}$ & $\begin{array}{c}\text { CORRUGATED } \\
\text { TUBES }\end{array}$ & $\begin{array}{c}\mathrm{R}_{\mathrm{e}} \\
\text { NUMBER }\end{array}$ & $\begin{array}{l}\text { NUSSELT } \\
\text { NUMBER }\end{array}$ & $\begin{array}{c}\text { FRICTION } \\
\text { FACTOR }\end{array}$ & $\begin{array}{c}\text { HEAT } \\
\text { TRANSFER }\end{array}$ \\
\hline $\begin{array}{c}\text { Hamedsadighidi } \\
\text { zaji[17] } \\
\& \\
\text { Concave and } \\
\text { convex }\end{array}$ & Imer thbe: Conres & $\begin{array}{l}3500- \\
18,000\end{array}$ & $15-110 \%$ & $150-250 \%$ & $26-38 \%$ \\
\hline $\begin{array}{l}\text { H. Pehlivan[18] } \\
\& \\
\text { Corrugated } \\
\text { Channel }\end{array}$ & & $\begin{array}{c}4000- \\
7400\end{array}$ & - & - & $16-22 \%$ \\
\hline
\end{tabular}




\begin{tabular}{|c|c|c|c|c|c|}
\hline $\begin{array}{c}\text { Primozporedos[1 } \\
9] \\
\& \\
\text { Double pipe } \\
\text { Corrugated }\end{array}$ & 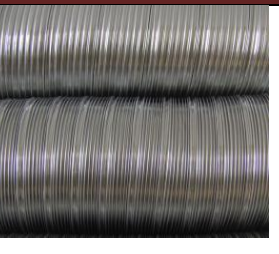 & - & $55-90 \%$ & - & $65-90 \%$ \\
\hline $\begin{array}{c}\text { S. Rainieri[20] } \\
\& \\
\text { Helically } \\
\text { Coiled wall }\end{array}$ & & $\begin{array}{l}7000- \\
12000\end{array}$ & $17-25 \%$ & $20-25 \%$ & $10-25 \%$ \\
\hline $\begin{array}{c}\text { Vamsimokkapati } \\
{[21]} \\
\& \\
\text { Corrugated } \\
\text { With twisted } \\
\text { taps }\end{array}$ & & $\begin{array}{c}33000- \\
68000\end{array}$ & & & $8-67 \%$ \\
\hline $\begin{array}{c}\text { Shivedayalpande } \\
\text { y[22] } \\
\& \\
\text { Corrugated } \\
\text { Plate }\end{array}$ & 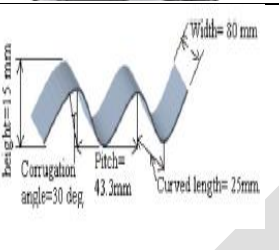 & $\begin{array}{c}5000- \\
7700\end{array}$ & & & $83-87 \%$ \\
\hline $\begin{array}{c}\text { Yuxianghong[23 } \\
] \\
\& \\
\text { Spiral grooved } \\
\text { with TT }\end{array}$ & & $\begin{array}{l}8000- \\
22000\end{array}$ & - & $16-45 \%$ & $59-79 \%$ \\
\hline
\end{tabular}

Table 2: Properties of nano-fluids used

\begin{tabular}{|c|c|c|c|c|}
\hline Nano fluid name & $\begin{array}{c}\text { Nano particle size } \\
(\mathrm{nm})\end{array}$ & $\begin{array}{c}\text { Density } \\
(\mathrm{kg} / \mathrm{m} 3)\end{array}$ & $\begin{array}{c}\text { Specific heat } \\
(\mathrm{J} / \mathrm{Kg} \mathrm{K})\end{array}$ & $\begin{array}{c}\text { Thermal conductivity } \\
(\mathrm{W} / \mathrm{mK})\end{array}$ \\
\hline $\mathrm{Al}_{2} \mathrm{O}_{3}[24]$ & $>50$ & 3970 & 525 & 17.65 \\
\hline $\mathrm{Fe}_{2} \mathrm{O}_{3}[25]$ & 40 & 4845.4 & 4179 & 0.631 \\
\hline $\mathrm{SiO}_{2}[26]$ & 30 & 2220 & 745 & 1.4 \\
\hline $\mathrm{TiO}_{2}[27]$ & 50 & 4175 & 692 & 8.4 \\
\hline $\mathrm{CuO}[28]$ & $30-50$ & 89.33 & 385 & 500 \\
\hline $\mathrm{ZnO}[29]$ & $>100$ & 5610 & - & 50 \\
\hline Ethylene glycol[30] & 150 & 1030 & 3.90 & 0.512 \\
\hline
\end{tabular}

\subsection{PERFOMANCE ANALYSIS OF HEAT EXCHANGER USING NANO FLUIDS}

The author P.V.Durga Prasad and K.Deepak used $\mathrm{Al}_{2} \mathrm{O}_{3}$ as a nano fluid in their experiment and observed that $34.24 \%$ increase in nusselt number and 1.29 times increase in friction factor at $0.03 \%$ volume concentration when compared with water[24]. Another authors E.Esmaeilzadeh, H. Almohammadi, A. Nokhosteen, A. Motezaker, A.N. Omrani made a comparative study on the heat 
transfer enhancement by varying the thickness of the twisted plates using $\mathrm{Al}_{2} \mathrm{O}_{3}$. It is found thatthe convective heat transfer ishigher for the maximum thickness $(2 \mathrm{~mm})$ and also for the higher volume concentration [25]. The authors Mohammad HosseinAghabozorg, AlimoradRashidi, Saber Mohammad used $\mathrm{Fe}_{2} \mathrm{O}_{3}$ as their nanofluid and showed a higher heat transfer of $27.69 \%$ at 0.1 volume concentrations and $37.50 \%$ at 0.2 volume concentration comparing with the base fluid [26]. Another authors L. SyamSundar, Antonio C.M. Sousa, Manoj K. Singh used $\mathrm{Fe}_{3} \mathrm{O}_{4}$ and gave the comparative results of friction factor increased by $50.99 \%$ at $\mathrm{Re}=22000$ at $0.3 \%$ volume concentration [27]. The authors W.H.Azmi, K.V.Sharma, RizalmanMamat used two nano fluids. $\mathrm{SiO}_{2}$ gave $27.9 \%$ higher heat transfer coefficient at 3\% volume concentration compared with water while $\mathrm{TiO}_{2}$ gave $11.4 \%$ higher heat transfer coefficient at 3\% concentration compared with water [28]. The authors KhwanchitWongcharee and Smith Eiamsa-ard used $\mathrm{CuO}$ where he found increased heat transfer rate 2.67 times and friction factor 5.76 times than the normal tube at $0.7 \%$ volume concentration withtwist ratio 2.7 at $\mathrm{Re}=6200$ [29]. The author I.M. Shahrul, I.M. Mahbubul, R. Saidurmade, madea comparative study between $\mathrm{Al}_{2} \mathrm{O}_{3}, \mathrm{SiO}_{2}$ and $\mathrm{ZnO}$. The highest heat transfer rate was found with $\mathrm{ZnO}$ around $35 \%$ than the other fluids [30]. V. Kumaresan, R. Velraj and Sarit K. Das used ethylene glycol and showed a increase of maximum $160 \%$ in heat transfer coefficient for $0.45 \%$ volume concentration MWCNT [31]. A special type of nano fluid named nitrogen-doped, graphene based nano fluid was used by MarjanGoodarzi, MasoudAfrand, EmadSadeghinezhad, SomchaiWongwises, M. Dahari. The NDG was made in a aqueous solution of $0.025 \mathrm{wt}, \%$ Triton $\mathrm{X} 100$ as a surfactant. They showed $15.86 \%$ increase in convective heat transfer coefficient than water at $0.06 \%$ weight concentration [32]. A hybrid variety of nano-fluid was proposed by H.R. Allahyar, F. Hormozi, B. ZareNezhad. It contains $97.5 \%$ alumina and $2.5 \% \mathrm{Ag}$. The maximum heat transfer is obtained $31.58 \%$ higher than the distilled water at $0.4 \%$ volume concentration [33]. The authors R. Dharmalingam, K.K. Sivagnanaprabhuand B. Senthilkumar experimented with $\mathrm{Al}_{2} \mathrm{O}_{3}$ and silver in the solar flat plate collectors to enhance the heat transfer rate and obtained a maximum efficieny of $78.6 \%$ with volume concentration of $0.04 \%$ [34] [35].

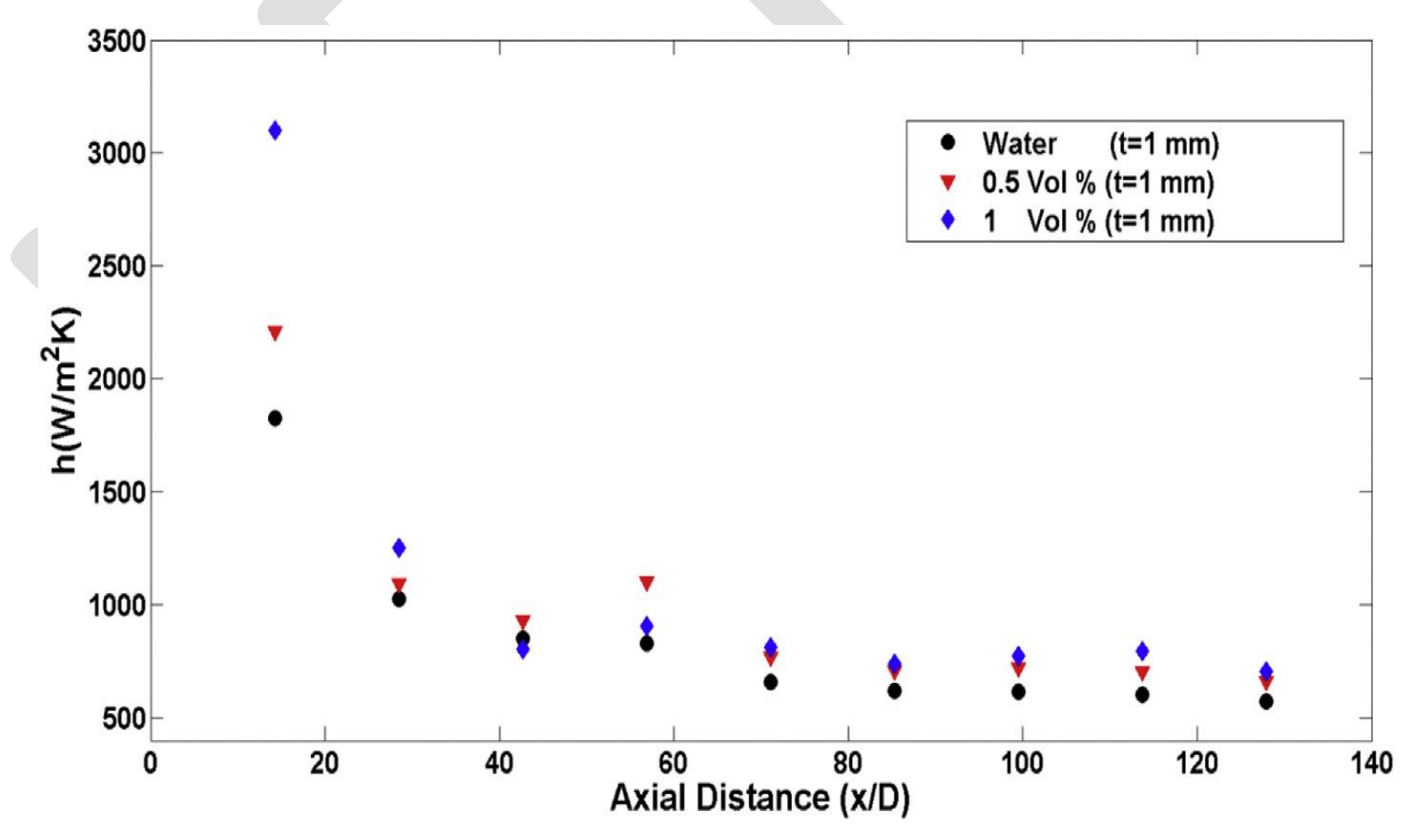

Fig 1: Graphical representation Axial distance (vs) Heat transfer coefficient.

The above graph gives a graphical representation of heat transfer vs axial distance using $\mathrm{Al}_{2} \mathrm{O}_{3}$ as a nano fluid done by E.Esmaeilzadeh. It clearly shows that the heat transfer rate increases for nano fluid than normal water and also at higher volume concentrations. 


\section{RESULT}

In this review paper we clearly found that the maximum heat transfer occurs when both tubes are corrugated made up of aluminium strip. Then heat transfer is increased by $65-90 \%$ and nusselt number increased by $55-90 \%$ [19]. And also when the nano fluids are used as a working fluid the heat transfer also gets increasing, When ethylene glycol is used as a working fluid the heat transfer is increased by $160 \%$ in heat transfer coefficient for $0.45 \%$ volume concentration[31].

\section{CONCLUSION}

Thus the corrugated tube and nano-fluids plays a important role in heat exchanger for the effective transfer of heat from one fluid to other one with the aid of different structures of corrugated and different nano fluids available. The researcher is free to choose any kind of nano fluid based on their need, cost, applications. With the use of corrugated and nano fluids in a normal heat exchanger, we can

- Enhance the convective heat transfer coefficient, $\mathrm{h}$

- Increase the friction factor, $\mathrm{f}$

- Increase the Nusselt number, $\mathrm{Nu}$

- Reduction in pressure drop, $\mathrm{P}$

\section{REFERENCES}

[1] Martinus, A.Arie, Amir H. Shooshtari, RatneshTiwari, Serguei V. Dessiatoun, Michael, Experimental Characterization of Heat Transfer in an Additively Manufactured Polymer Heat Exchanger.

[2]Zhi-jiang Jin, Fu-qiang Chen, Zhi-xinGao, Xiao-feiGao, Jin-yuanQian Effects of pitch and corrugation depth on heat transfer characteristics in six-start spirally corrugated tube, International Journal of Heat and Mass Transfer 108 (2017) 1011-1025

[3]A.A.Sertkaya, K.Altınısık ,K.Dincer, Experimental investigation of thermal performance of aluminum finned heat exchangers and open-cell aluminum foam heat exchangers, Experimental Thermal and Fluid Science 36 (2012) 86-92

[4] VentsislavZimparov, Prediction of friction factors and heat transfer coefficients for turbulent flow in corrugated tubes combined with twisted tape inserts. Part 1: friction factors, International Journal of Heat and Mass Transfer 47 (2004) 589-599

[5] YiminXuan, Qiang Li, Heat transfer enhancement of nanofluids, International Journal of Heat and Fluid Flow 21 (2000) 58-64

[6] Hwang Y, Lee JK, Jeong YM, Cheong S, Ahn YC, Kim SH. Production and dispersion stability of nanoparticles in nanofluids. Powder Technol 2008;186:145-53.

[7] Das SK, Putra N, Thiesen P, Roetzel W. Temperature dependence of thermal conductivity enhancement for nanofluids. J Heat Transf 2003;125(4):567-74.

[8] Wang XQ, Mujumdar AS. Heat transfer characteristics of nanofluids: a review. Int $\mathbf{J}$ ThermSci 2007;46(1):1-19. 
[9] Wang XQ, Mujumdar AS. A review on nanofluids-part II: experiments and applications. Braz J ChemEng 2008;25(4):631-48.

[10] Eastman JA, Choi SUS, Li S, Yu W, Thompson LJ. Anomalously increased effective thermal conductivities of ethylene glycol- based nanofluids containing copper nanoparticles. ApplPhysLett 2001;78(6):718-20.

[11] Pak BC, Cho YI. Hydrodynamic and heat transfer study of dispersed fluids with submicron metallic oxide particles. Exp Heat Transf 1998;11(2):151-70.

[12] Hussein AM, Bakar RA, Kadirgama K, Sharma KV. The effect of nanofluid volume concentration on heat transfer and friction factor inside a horizontal tube. J Nanomater 2013:1-12.

[13] Duangthongsuk W, Wongwises S. An experimental study on the heat transfer performance and pressure drop of $\mathrm{TiO} 2$-water nanofluids flowing under a turbulent flow regime. Int $\mathrm{J}$ Heat Mass Transf 2010;53:334-44.

[14] Hussein AM, Sharma KV, Bakar RA, Kadirgama K. Study of forced convection nanofluid heat transfer in the automotive cooling system. Case Study ThermEng 2014;2:50-61.

[15] Hwang Y, Lee J, Lee C, Jung Y, Cheong S, Ku B, Jang S. Stability and thermal conductivity characteristics of nanofluids. ThermochimActa 2007;455:70-4.

[16] Li X, Zhu D, Wang X. Evaluation on dispersion behavior of the aqueous copper nanosuspensions. J Colloid Interface Sci 2007;310:456-63.

[17] HamedSadighiDizaji, SamadJafarmadar, FarokhMobadersani, Experimental studies on heat transfer and pressure drop characteristics for new arrangements of corrugated tubes in a double pipe heat exchanger, International Journal of Thermal Sciences 96 (2015) 211e220.

[18] H. Pehlivan, I. Taymaz, Y. İslamoğlu, Experimental study of forced convective heat transfer in a different arranged corrugated channel, International Communications in Heat and Mass Transfer 46 (2013) 106-111

[19] Primo Poredo, TomaSuklje, SasoMedved, CirilArka, An experimental heat-transfer study for a heat-recovery unit made of corrugated tubes, Applied Thermal Engineering 53 (2013) 49e56

[20] S. Rainieri, F.Bozzoli, L.Cattani, G.Pagliarini, Compound convective heat transfer enhancement in helically coiled wall corrugated tubes, International Journal of Heat and Mass Transfer 59 (2013) $353-362$

[21] VamsiMokkapati, Chuen-Sen Lin, Numerical study of an exhaust heat recovery system using corrugated tube heat exchanger with twisted tape inserts, International Communications in Heat and Mass Transfer 57 (2014) 53-64

[22] ShiveDayalPandey, V.K.Nema, Experimental analysis of heat transfer and friction factor of nanofluid as a coolant in a corrugated plate heat exchanger, Experimental Thermal and Fluid Science 38 (2012) 248-256 
[23] Yuxiang Hong, Juan D, Shuangfeng Wang, Experimental heat transfer and flow characteristics in a spiral grooved tube with overlapped large/small twin twisted tapes, International Journal of Heat and Mass Transfer (2016)

[24] P.V. Durga Prasad, A.V.S.S.K.S. Guptaand K. Deepak, Investigation of Trapezoidal-Cut Twisted Tape Insert in a Double Pipe U-Tube Heat Exchanger using A12O3/Water Nanofluid, Procedia Materials Science 10 ( 2015 ) 50 - 63.

[25] E. Esmaeilzadeh, H. Almohammadi, A. Nokhosteen, A. Motezaker, A.N. Omrani, Study on heat transfer and friction factor characteristics of $\Upsilon$-Al2O3/water through circular tube with twisted tape inserts with different thicknesses, International Journal of Thermal Sciences 82 (2014) 72-83.

[26] Mohammad HosseinAghabozorg, AlimoradRashidi, SaberMohammadi, Experimental investigation of heat transfer enhancement of Fe2O3-CNT/water magnetic nanofluids under laminar, transient and turbulent flow inside a horizontal shell and tube heat exchanger, Experimental Thermal and Fluid Science 72 (2016) 182-189.

[27] L. SyamSundar, G. Otero-Irurueta, Manoj K. Singh, Antonio C.M. Sousa, Heat transfer and friction factor of multi-walled carbon nanotubes-Fe3O4 nanocompositenanofluids flow in a tube with/without longitudinal strip inserts, International Journal of Heat and Mass Transfer 100 (2016) 691-703.

[28] W.H.Azmi, K.V.Sharma, RizalmanMamat, and ShahraniAnuar, Turbulent forced convection heat transfer of nanofluids with twisted tape insert in a plain tube, Energy Procedia 52 ( 2014 ) 296 307.

[29] KhwanchitWongcharee, Smith Eiamsa-ard, Heat transfer enhancement by using CO/water nanofluid in corrugated tube equipped with twisted tape, International Communications in Heat and Mass Transfer 39 (2012) 251-257.

[30] I.M. Shahrul, I.M. Mahbubul, R. Saidur, M.F.M. Sabri, Experimental investigation on Al2O3$\mathrm{W}, \mathrm{SiO} 2-\mathrm{W}$ and $\mathrm{ZnO}-\mathrm{W}$ nanofluidsand their application in a shell and tube heat exchanger, International Journal of Heat and Mass Transfer 97 (2016) 547-558.

[31] V. Kumaresan, R. Velraj, Sarit K. Das, Convective heat transfer characteristics of secondary refrigerant based CNT nanofluids in a tubular heat exchanger, International Journal of Refrigeration 35 (2012) 2287-2296.

[32] MarjanGoodarzi, A.Sh. Kherbeet, MasoudAfrand, EmadSadeghinezhad, Mohammad Mehrali,PeymanZahedi, SomchaiWongwises, M.Dahari, Investigation of heat transfer performance and friction factor of a counter-flow double-pipe heat exchanger using nitrogen-doped, graphenebased nanofluids, International Communications in Heat and Mass Transfer 76 (2016) 16-23.

[33] H.R. Allahyar, F. Hormozi, B. ZareNezhad, Experimental investigation on the thermal performance of a coiled heat exchanger using a new hybrid nanofluid, Experimental Thermal and Fluid Science 76 (2016) 324-329.

[34] R. Dharmalingam, K.K. Sivagnanaprabhu, C. Chinnasamy and B. Senthilkumar, Optimization Studies on the Performance Characteristics of Solar Flat - Plate Collector Using Taguchi Method, Middle-East Journal of Scientific Research 23 (5): 861-868, 2015. 
[35] R. Dharmalingam, K.K. Sivagnanaprabhu, S. Periyasamy and B. Senthilkumar, Experimental investigation and mathematical study of performance characteristics of solar flat plate collector using A12O3 / water nanofluid,International Journal of Mechanical Engineering and Research, ISSN 09734562 Vol. 5 No.1 (2015). 